On the Nile Flood and Its Variation: Discussion

Author(s): Colin Scott Moncrieff, John Eliot, W. M. Shaw, M. G. Talbot, H. R. Mill, Dr.

Herbertson, Thomas Holdich, Mr. Chisholm, J. A. Baines and Captain Lyons

Source: The Geographical Journal, Vol. 26, No. 4 (Oct., 1905), pp. 415-421

Published by: geographicalj

Stable URL: http://www.jstor.org/stable/1776605

Accessed: 21-06-2016 08:53 UTC

Your use of the JSTOR archive indicates your acceptance of the Terms \& Conditions of Use, available at

http://about.jstor.org/terms

JSTOR is a not-for-profit service that helps scholars, researchers, and students discover, use, and build upon a wide range of content in a trusted digital archive. We use information technology and tools to increase productivity and facilitate new forms of scholarship. For more information about JSTOR, please contact support@jstor.org.

The Royal Geographical Society (with the Institute of British Geographers), Wiley are collaborating with JSTOR to digitize, preserve and extend access to The Geographical Journal 
From this it is evident that the agreement is not invariable; in years of excessive precipitation, or of famine, the favourable or the unfavourable conditions will be at their strongest, and therefore will be most likely to extend widely. The test cases should be drawn from the years of more normal conditions. In these twenty-eight years, 1876, 1883, 1891, 1895, 1896 were above the mean in Egypt and below it in India, while 1881, 1882, 1884, 1886 were below the mean in Egypt and above it in India; thus nine years out of twenty-eight are not in agreement. Some do not differ widely from the mean, but they are not concordant, and show that the south-west monsoon is not by itself a safe guide to the character of the Abyssinian rains.

This investigation has now been carried further, and it has been found that a close relation exists between + and - anomalies of atmospheric pressure over Egypt and the neighbouring areas, and the defect or excess in the volume of the Nile flood. That such meteorological phenomena show a comparatively short period of oscillation has been pointed out by Sir J. Eliot, Sir N. Lockyer, Dr. W. J. Lockyer, Prof. Bigelow, and others. In the case of the Nile floods, local meteorological conditions affect this oscillation and increase the irregularity. Generally, then, it may be said that, so far as our knowledge goes at present, the Nile flood depends on, primarily, the strength of the monsoon air-currents from the Indian ocean, but modified by the pressure conditions which exist over North-East Africa, as I have shown in a recent paper.*

The following discussion took place:-

Sir Colin Scomt MoncriefF: I do not know that I have much to say. I listened to Captain Lyons's paper and also read it with a great deal of interest. The way he is proceeding to show what does not cause the Nile flood is very satisfactory. By degrees we shall perhaps get at what does cause it. For a number of years $I$ took the greatest interest in this matter, and these curves we have before us call back to my mind the way I made them out day by day, and kept the register of the Nile gauge for nine years. We got our readings every day from Kbartum, from Berber, and from Wadi Halfa, until one fine morning the rain-gauge did not come in from Khartum, and it did not come in for about fifteen years, for the Mahdi was ruling the Sudan. After we first had our information cut off from Khartum, I tried $t$ s find if there was any connection with the rainfall at Zanzibar; but I could make nothing out of it. I was not encouraged at that time to believe there was much connection with the rains in India. We must just go on working, and by degrees I hope we shall get to the right thing. I am sure we are very much obliged to Captain Lyons, who has done more on this subject than all his predecessors put together.

Sir JoHN ELIOT: I might perhaps make one or two remarks. I am not quite certain whether there is some connection between the rainfall in India and in Abyssinia and the Nile regions, but I think it is only sufficient to mention the year 1899. The deficiency in India in 1899 was phenomenal. I have just heard

* "On the Relition betwcen Variation of Atmosplieric I'ressure in North-Jast Ifrica and the Nile Flood," Proc. Roy. Soc., 1905. 
from Captain Lyons that the Nile flood as indicated or measured by the gauge at Assuan was the lowest on record. The rainfall was deficient in the same year in the Mauritius, South Africa, and also in parts of Australia. I think that is quite sufficient to show there seems to be some very large connection between the rainfall in the whole of the Indo-oceanic area. I cannot give you data at present, and I can only give you that one case. In respect to the comparison with the rainfall in India, I would like to make one suggestion, as I have bad something to do with drawing up the figures. There are two elements-first, as to whether you take your readings at a sufficient number of stations; and, secondly, whether you have rainfall data for a sufficient number of years to give you an approximate average for that area. I am not quite certain whether we have got to that stage in India as yet. When it comes to small variations for the whole of India, plus or minus, if you were to arrange the stations differently, it is $v \in$ ry possible jou would get different variations. For comparisons between rainfall variations in two areas, I. should go more upon the correspondence of large variations than I should upon the correspondency of two curves. The only other point I wish to mention is the conclusion at which Captain Lyons arrives. He says, " Generally, then, it may be said that, so far as our knowledge goes at present, the Nile flood depends on, primarily, the strength of the monsoon air-currents from the Indian ocean, but modified by the pressure conditions which exist over North-East Africa." That is exactly what I have found for many years past in India, and of those two effects, the largest is prcduced by the Indian ocean. I think the paper is a most valuable one, and I only wish I had had the information contained in it five years ago.

Dr. W. M. SHaw : In relation to what Sir Colin Scott Moncrieff has said, we may find encouragement in the paper for meteorological work, from the conclusion that the flood conditions of Lower Egypt depend upon the rainfall in Abyssinia. The relation of conditions in Lower Egypt and in Abyssinia is easy to accept, because there is a river to connect them. There are connections in other parts of the world which really exist and deserve to be traced out, although one cannot point to a river on the map as the connection between them. For that reason we have reason to be grateful to Captain Lyons for the exergetic way in which he is looking after his neighbours' observations. Observations are often taken with the understanding and the hope that they may be useful to other people, if not to ourselves. When that hope gets faint, there is a tendency for the observer to be discouraged. If Captain Lyons has done nothing else, he has shown that observations in widely different parts of the world may be of real importance to neighbours in the first place, and to the whole community in the second place. The determination of the relation or want of relation between plotted curves of variations of various elements from year to year is a subject that grows in importance as successive people take it up. It requires, I presume, an accomplished mathematician to deal with the curves and their periods, but our information is slowly accumulating, and I have no doubt that if we could get together a body of persons devoted to studying the relations of the meteorological phenomena of one country to those of others in the way that Sir John Eliot has suggested, and the India Office is, I believe, prepared to support, we should feel our gratitude to Captain Lyons strengthened by the fact that the observations he has organized, examined, and put together will contribute towards placing the relations between the meteorological conditions of different countries beyond cavil or doubt.

Colonel Hon. M. G. TALBot : I should like, as a late Sudan official, to testify to the thoroughness of Captain Lyons' work there. You have notic $\in d$, naturally, that all the data obtained in this paper has been obtained through the Egyptian and not the Sudan Government, and the same applies to the meteorological 
data that Captain Lyons has collected and embodied in his other papers on the meteorological conditions of the Nile basin. The Sudan Government was sympathetic, but it had neither the money to provide the necessary instruments and observers, nor had it any one nearly so well qualified to undertake the superintendence as Captain Lyons. Captain Lyons and I have often corresponded regarding the observations, sending out instruments, and that sort of thing, and knowing well the great difficulties he has had to contend with, not only in the way of providing the necessary instruments, but in getting reliable observers in the Sudan, I can testify how entirely the collection of the meteorological data in the Sudan, so important for the study of the Nile flood, is due to his initiative and unceasing push and energy.

Dr. H. R. MILL: This paper is one which I think is of very special interest to this Society, because it brings to the solution of a geograpbical problem the facts that are ascertained by the study of another science-meteorology. In hearing this discussion of the Nile flood, the first idea, I think, that must come into the mind of any geographer is that the supposed importance of the Victoria Nyanza has been greatly diminished. I remember very well when we were endeavouring to start meteorological observations in tropical Africa, the work that Mr. Ravenstein took up with such energy and success there gave great hopes that the observations of rainfall round the great lakes were going to open a way to the solution of the problem of the changes in the floods of the Nile; this is now shown to be a mistake. The centre of the problem has been shifted back to the rainfall on the Abyssinian heights ; and that this rainfall has the whole responsibility of producing the floods has been clearly brought out by Captain Lyons's paper. There is one fact on which he touched, but did not fully treat, that, I think, shows his estimate of the dependence of the floods on the Abyssinian rains to be almost numerically correct. When the variations in the height of the flood were expressed as a ratio to the mean flood, I noticed that these variations almost exactly correspond with the well-known variations of rainfall as they have been determined, not in this country only, but all over the world; that is to say, that the minimum year's rainfall is something approaching two-thirds of the average, and the maximum is something apprcaching one and a half times the average-rather more than twice the minimum. But a still more clearly established relationship with regard to rainfall averages is the average of the three dryesi consecutive years that are likely to be experienced. The three dryest consecutive years in any period of thirty-five years and more have been found-and this relation holds in all parts of the world-to be about 80 per cent. of the true average fall. Now, I have looked at those figures of the Nile ratio here, and I find that the three dryest years, 1899, 1900, 1901, come out almost exactly with a ratio of 80 per cent. to the average, and that certainly would, on the face of it, suggest that the Nile flood is a direct measure of the rain of the district that produces it. I am not quite sure how far there may be variations in the evaporation; but I suppose that the climate of Abyssinia and the Sudan is so nearly invariable that there is not a very large difference between one year and another. It will be extremely interesting, and, I should say, absolutely necessary, to get observations set on foot in Abyssinia, so that we may have actual figures, and not merely indications, to go upon. And I think, from the energy with which Captain Lyons is pursuing his investigations in that direction, this result will be obtained before long. It would be a great thing if this Society and other learned societies could do something to help that forward. But a remark that fell from Sir John Eliot, I think, is more important than the establishment of isolated stations; that is, the comparative study of the results when obtained. Sir John Eliot laid stress,

No. IV.-ОстовеR, 1905.]

$2 \mathrm{~F}$ 
wisely, on the extreme danger of deducing rainfall averages over large areas of country from an inadequate number of stations. His remark points to the necessity of using, not the station, but the area as the unit, and of studying the rainfall question from a geographical quite as much as from a meteorological point of view. I am now endeavouring to do this with regard to British rainfall. The number of stations, I am happy to say, is now about 4000 , but even with all these the difficulty of ascertaining the relative wetness of different years in a long period is great, and it seems quite hopeless to attempt to do so by comparing any one individual station with another. The only way I see for getting the basis for a strictly scientific comparison of the variations of rainfall from year to year for the country as a whole, or any large region, is to work out the rainfall each year on different areas, and then by some method, either by arithmetical treatment or otherwise, get the averages for a long time.

Dr. HERBERTson: I had no intention of speaking this afternoon, but I am very glad of the opportunity of thanking Captain Lyons for this most valuable contribution to a problem which has interested mankind for many centuries. It occurred to me during the reading of the paper and the subsequent speakers' remarks that it is very necessary that there should be some organization for discussing the meteorological observations in distant parts of the world. One would like to see a sort of International Meteorological Bureau, which would deal with meteorological observations from a selected number of stations for the whole world, and regularly discuss the world distribution of meteorological elements, their normal sequences and variations. In the case of the rainfall of Abyssinia, we obviously have to deal with pressure conditions where there is a baric ridge with sinking gradients to south and north. We want to know the normal conditions of pressure in this ridge and its slopes, the height of the barometer along the maximum area, and the relations to surrounding baric maxima and minima, and the depressions in the minima. That cannot be ascertained by one observer, nor dealt with satisfactorily by one of the ordinary weather bureaus. It requires a special bureau to discuss so large a question. Another matter which occurred to me was, how far the water of these Abyssinian rivers could be used for irrigation in the lower part of their courses before they reached the Nile, and how far that would affect the supply of water to the irrigation canals of Egypt. A last point is, may we not still see a great use in the equatorial rainfall and the Victoria Nyanza, and other lake basins, in keeping the level of the Nile constant during the winter months in Egypt, and so helping the perennial irrigation in the lower courses of the river?

Sir Thomas Holdich : I am not an Egyptian official, neither do I belong to the Sudan, but as an outsider perhaps I may be allowed to give one little bit of evidence. In the year $1868 \mathrm{I}$ was doing the best I could to survey the upper sources of the Atbara at the beginning of the monsoon season. You may remember, perhaps, that one of the main difficulties of effecting a dignified retirement from Abyssinia at the close of the expedition was the coming of the rains, which washed down with such force that in some of the narrower gorges the level of the water was raised 18 feet. You will admit, I think, that I was not at a bad point for observation, for there to the east we had the Red sea, with Annesley bay below us, and on the west the Nile basin leading to the Mediterranean. I am positively certain that on that occasion, at any rate, the commencement of the monsoon influenced both areas. The same wind, the same general lowering temperature, the same variations of weather which prevailed in the Red Sea at that time (and which were exceedingly inconvenient to the expedition), prevailed also on the Abyssinian plateau, and sent down floods to the Nile, From that day to this I have always believed the south-west monsoon to be the origin of rainfall 
simultaneously in the Nile basin and in India, however unequally that rainfall may happen to be distributed.

Mr. Chishorm : The only observation I have to make on this very interesting paper is one suggested by something that has just been mentioned by Sir Thomas Holdich. It seems to me that one of the most important points brought before this meeting by the paper of Captain Lyons, viz. the fact that the floods of the Nile are mainly due to the drainage of the Abyssinian mountains, and not so much to the White Nile, is one that need not have excited, in the circumstances, any very great amount of surprise. Sir Thomas Holdich has just told us of the remarkably sudden rise of the rivers in Abyssinia, of which he had been a witness, and that induces me to ask him whether he can say anything with regard to the geological structure of Abyssinia; that is to say, whether Abyssinia is to a very large extent composed of a very hard rcck-a hard impermeable rock that would not allow rain to sink in.

Sir Thomas Holdich : Yes, it is so.

Mr. Chishorm : That being so, this structure, combined with the differences in altitude in Abyssinia, will have the effect that what rain falls there will find its way with remarkable speed into the mountain river, and ultimately cause a rapid change in the amount of flood in the Blue Nile at the junction of the White Nile. We know that in the Sudan the conditions are entirely different. We have there a vast alluvial country into which the rainfall will in a large measure gradually percolate into the streams, and in a large measure be brought to the surface again by capillarity and re-evaporated. Through such differences in physical conditions we have enormous differences in the behaviour of the rivers in different parts of the world. I believe, for example, it is the case that the maximum discharge of the Mahánadi may reach on certain occasions as high as that of the Ganges; but in the case of the Mahánadi the maximum may last for twelve hours, while in that of the Ganges it will go on for about three weeks, this difference arising from the fact that the Ganges flows through vast alluvial flats, whereas the Mahánadi flows through an area of hard crystalline rocks with steep slopes.

Mr. J. A. BarNes : Sir John Eliot has pointed out one instance of remarkable coincidence between the rainfall of Western India and the height of the flood on the Blue Nile, and there appears, also, to be a less marked but still perceptible instance of the same character in 1877. Both these, however, are in the direction of abnormal deficiency of rainfall, and to establish the fact that the influonce of violent oscillations from the mean is common to both regions, it is necessary to ascertain that abnormal excess also is simultaneous. Perhaps Sir John Eliot, whose knowledge of the Indian monsoon is unrivalled, may be able to quote a year or two in which the fall, not merely on the west coast of India, but about 100 miles inland, was inarkedly above the average, so that we can see on the diagram whether a corresponding excess was recorded in the Abyssinian highlands. Another point which seems worth explanation is the very remarkable difference between the curve of quinquennial average variation on the Nile before and after the early seventies. The earlier curves appear to vary from year to year, whilst, of late, several years in succession seem to be subject to the same influence, and the curve is thus much more extended.

Captain Lyons: I am very glad Sir John Eliot agrees with me in my conclusion at the end as to the possible local effect on the variations of pressure. I may be over-sanguine, but my own feeling is, if we study the meteorology, not only of the Sudan, but of the other areas to the south, we may be able to form an estimate whether the rainfall in Abyssinia is likely to increase or decrease for a month ahead. This year a beginning was made, and rainfall was telegraphed

2 F 2 
monthly from Uganda and British East Africa; in the latter area it was good, in the former poor, while on the Bahr-el-Jebel, particularly in April and May, it absolutely failed. The result was that the Sobat and the Blue Nile were nearly three weeks late in their first rise, as was to be expected. Dr. Mill spoke of the Victoria Nyanza as having been practically eliminated from the question, and asked about the effect of the Victoria Nyanza at the low stage of the Nile. Captain Owen, whose map was published in the Journal a short time ago, and also others, have told me there appears no doubt that the water-level in the Mruli-Foweira reach of the Nile is practically constant throughout the year, dry or rainy season, and the river is bank full there, so that the volume discharged is practically constant. Variations of discharge at the Ripon falls are regulated in the l. w marshy depression of Lakes Choga and Rawania. The discharge measured by Sir W. Garstin in March, 1903, below the Murchison falls, certainly was practically the same as that at Foweira at that season; that is to say, 550 to 560 cubic metres a second, constantly, throughout the year, represents the amount supplied by the Victoria Nyanza and its basin. The low stage of the Nile to which Dr. Herbertson referred raises another point. Throughout the year, at the mouth of the Bahr-elJebel, there is a constant discharge of nearly 300 cubic metres a second, because the marshes take up both the flood and the local rains of the summer. Therefore, adding the Bahr-el-Ghazal and Bahr-el-Zaraf, the constant discharge that goes down to the White Nile is about 400 cubic metres a second. The variable factors are the Sobat and the Blue Nile; if the rains are very heavy, and a certain amount is taken up in the soil, the springs are well filled, the rivers run down more slowly, and more water comes down the Sobat and the Nile in the winter. On the other hand, with moderate summer rains, which are continued, and even may become unusually heavy in September and October, although the flood may be a poor one, there may still be a good low-stage supply, because the Sobat and the Blue Nile are fed more than usual by the October rains. This happened in 1904, because the 1903 rains were continued well into September and October; exactly the opposite happened this year, when the 1904 rains failed in August, were very poor in September and October, and there was an extremely low-stage supply in consequence. With regard to the conditions of atmospheric pressure, to which Dr. Herbertson referred, I hope to publish something about that shortly. We have four years' observations for most stations, and two years for the others, our last station being within about 20 miles of the Uganda frontier. The main changes in the lines of the isobars appear to be, first of all, in the spring months, a low pressure forming over Abyssinia, which may have something to do with the quick advance of the early rains into Abyssinia. I am afraid, as regards the variation of the sharpness of the Nile flood curves, I am not able to give any explanation.

Sir Colin Sco'tr Monciifef : Might I ask a question? Supposing that the Victoria Nyanza was going down to Khartum, what would be the effect after that fills up the great spongy swamps? Is it not the case that in the month of March it is White Nile water, and not Blue Nile water, one is getting in Egypt?

Captain LyoNs : There is a constant supply of about 300 cubic metres per second from the White Nile above the Sobat, plus a certain amount from the Sobat, plus a certain amount from the Blue Nile, and it is the last two factors that vary. is it?

Sir Colin Scotr MoncriefF : But the Blue Nile is not very much at that time,

Captain Lyons: In a year of low supply it may discharge in May, but it is usually 300 cubic metres per second in the middle of January.

Sir Colin ScotT MoncriefF : I was in Khartum the other day, and there seemed to be nothing at all. 
Captain Lyoss: In the previous autumn rain in Abyssinia was very deficient; therefore there was nothing to fill up the springs, and the Blue Nile ran down rapidly; the Sobat supplied little, but there was the same constant discharge above the Sobat junction. It is the extra supply that ordinarily comes at the low stage from Abyssinia which decreases in the years when either the whole rainfall bas been feeble, or when the September and October rainfall has failed.

Sir Colin Scott Moncrieff : The practical question we always wished to solve in Egypt was to find what sort of forecast we could bave. As you say, I suppose it will be only by very careful examination of the great territories south of the Victoria Nyanza you will ever get at that.

Captain Lyovs: Yes, probably by studying the rains as they extend northwards, together with the meteorological conditions existing over the western part of the Indian ocean.

Sir J. Eliot : Is the Egyptian Service establishing any rainfall stations in Abyssinia?!

Captain Lyons: We have had instruments for two or three years at Addis Abbaba, but they need replacing, and it is difficult to send them there safely. The Russians and the Italians are taking observations there also. Three or four raingauges have been sent to other places, but no returns have yet been received.

The President : In proposing a vote of thanks, I wish to say I am not myself a specialist on these points, therefore I can only give an outside view. It seems to me we owe Captain Lyons a debt of gratitude in three ways. In the first place for the positive information chiefly in regard to the real causes of the rise of the Nile, which have been so much in dispute for a long time; in the second place, for the negative portion of the paper, in which he disproves the relation, so far as we can see it, between the sunspot curves and the flood curves; and in the third place, raising the question of any relation between the flood in Abyssinia and the rains in India. I think that will give rise to much discussion. Altogether, I think it has been a most admirable paper, and has given rise to much interesting discussion.

\section{SOME FURTHER NOTES CONCERNING THE LIAO HO.*}

By Lieut.-Colonel A. W. S. WINGATE.

Mr. Robert T. Turley contributes to the March number of the Journal (pp. 297-300) some interesting "Notes on the River System of the Upper Liao, Manchuria," accompanied by a "Sketch-map of the Liao River System," which, as the author justly says, should be of exceptional interest at the present juncture. With the object of maintaining that interest and of supplementing the valuable information contributed by Mr. Turley, the following notes have been written. Let me begin by calling attention to a fow misconceptions in Mr. Turley's notes and map.

1. First and foremost as to nomenclature. I have been at some pains to discover the true names of the river in question, and my

* The latitudes and longitudes are approximate only, being derived from Russian maps checked by plane-table traverse. The exception is Hata, the data for which were furnished by Major Goold-Adams, R.A. 